\title{
SPERM ASCENT THROUGH THE OVIDUCT OF THE HAMSTER AND RABBIT IN RELATION TO THE TIME OF OVULATION
}

\author{
R. YANAGIMACHI AND M. C. GHANG \\ Worcester Foundation for Experimental Biology, Shrewsbury, Massachusetts and \\ Department of Biology, Boston University, Boston, Massachusetts, U.S.A.
}

(Received 29th May 1963)

\begin{abstract}
Summary. Female golden hamsters were mated either about 5 to $8 \mathrm{hr}$ before ovulation or about $2 \mathrm{hr}$ after ovulation. At various intervals after mating, a ligature was placed slightly above the intramural portion of the oviduct, thus preventing further sperm ascent. In the females mated before ovulation, the percentages of eggs fertilized, as examined 10 to $12 \mathrm{hr}$ after the estimated time of ovulation, were $16 \cdot 8,39 \cdot 6,58 \cdot 3$ and 81.4 when oviducts were ligated $1,2,4$ and $6 \mathrm{hr}$ after mating, respectively. In the females mated after ovulation, on the other hand, 37.5 and $92.0 \%$ of eggs were fertilized following ligation of oviduct at 0.5 and $1 \mathrm{hr}$ after mating, respectively. Examination of complete serial sections of oviducts fixed $1 \mathrm{hr}$ after mating showed that the oviducts of females mated after ovulation contained a relatively larger number of spermatozoa in their upper reaches than those of females mated before ovulation. It is concluded that in the hamster the ascent of spermatozoa through the oviduct takes place more rapidly when females are mated after ovulation than before ovulation. When rabbits were mated 8 and 4 $\mathrm{hr}$ before or $2 \mathrm{hr}$ after ovulation, and their utero-tubal junctions were ligated $2 \mathrm{hr}$ later, the fast sperm ascent after ovulation was not demonstrated.
\end{abstract}

\section{INTRODUCTION}

Sperm transport through the oviduct of the rodent has been studied by several workers. In the mouse, a few spermatozoa were recovered from the upper regions of the oviduct $15 \mathrm{~min}$ after mating (Lewis \& Wright, 1935). In the rat, spermatozoa were found in the ovarian segment of the oviduct 15 to 30 min after ejaculation (Blandau \& Money, 1944). According to Yamanaka \& Soderwall (1960), hamster spermatozoa were found in the ampullary portion of the oviduct within 2 min after ejaculation. Thus, the available evidences have been accumulated to show a rapid transport of spermatozoa through the oviducts.

In the rabbit, the spermatozoa seldom reach the oviduct within $1 \mathrm{hr}$ after mating. Thus, Braden (1953) was unable to recover spermatozoa from oviducts less than $3 \mathrm{hr}$ after mating. By means of post-coital ligation of the utero-tubal 
junction, Adams (1956) and Greenwald (1956) found that 5 to $6 \mathrm{hr}$ are required before sufficient spermatozoa enter the oviduct of all rabbits to fertilize all the eggs shed.

In the female rat and hamster oestrus lasts for about 13 to $18 \mathrm{hr}$ (Blandau, Boling \& Young, 1941; Soderall, Kent, Turbyfill \& Britenbaker, 1960) and ovulation occurs about 8 to $10 \mathrm{hr}$ after the onset of oestrus (Boling, Blandau, Soderwall \& Young, 1941; Blandau, 1952; Soderwall et al., 1960; Harvey, Yanagimachi \& Chang, 1961). Since the females will mate at any time during oestrus, it is of interest to determine whether or not the rate of sperm transport is affected by the time of mating. In the present study, the rate of sperm transport was assessed by ligating the lower part of the oviduct (or the utero-tubal junction) at various times after mating and subsequently examining eggs for evidence of fertilization. This was done because the entry of the first few spermatozoa into the oviduct does not necessarily imply that all the ova shed are fertilized by these vanguard spermatozoa.

\section{MATERIALS AND METHODS}

Adult virgin golden hamsters weighing between 100 and $150 \mathrm{~g}$ were used. Since the majority of females ovulate about $8 \mathrm{hr}$ after the onset of oestrus (Harvey et al., 1961), it is possible to mate females at specific times before and after ovulation. For the present study, the females were mated either within $3 \mathrm{hr}$ after the onset of oestrus (i.e. about 5 to $8 \mathrm{hr}$ prior to ovulation) or at about $10 \mathrm{hr}$ after the onset of oestrus (i.e. approximately $2 \mathrm{hr}$ after ovulation). In both cases, one female was introduced into a cage with two vigorous males. Generally, a large number of spermatozoa were found in the vagina within the first $10 \mathrm{~min}$ after the start of copulation. Females were allowed to copulate with two males for about $30 \mathrm{~min}$.

At various intervals after the start of copulation, the right genital tract of each female was exposed mid-ventrally under ether anaesthesia. The uterus was moderately stretched and a mass of spermatozoa engorging the whole length of the uterus was gently squeezed towards the posterior half of the uterus. A tight ligature with fine thread was then placed slightly above the intramural region of the oviduct (see Text-fig. 1), special care being taken to avoid damage to the blood vessels. The left oviduct was not ligated and served as control. Between 10 and $12 \mathrm{hr}$ after the estimated time of ovulation, the eggs were recovered from the ampullae and examined for evidences of fertilization with a phase-contrast microscope (Yanagimachi \& Chang, 1961).

In another series, female hamsters were killed $1 \mathrm{hr}$ after the start of copulation and the ovaries, oviducts and uteri were removed intact and fixed in Bouin's fluid. In order to avoid accidental removal of uterine spermatozoa to the oviducts during sectioning, the organs were sectioned with a thoroughly cleaned microtome-knife, the ovary first, then the oviduct and lastly the uterus. Serial sections $(10 \mu)$ were stained with Ehrlich's haematoxylin and eosin.

In the third series, female rabbits were first injected intravenously with 45 i.u. luteinizing hormone to induce ovulation. Two hr after injection (about $8 \mathrm{hr}$ before ovulation), $6 \mathrm{hr}$ (about $4 \mathrm{hr}$ before ovulation) and $12 \mathrm{hr}$ (about 2 
$\mathrm{hr}$ after ovulation), each female was allowed to mate with a fertile male and the abundance of spermatozoa in the vaginal smear was verified. Two hours after mating the utero-tubal junctions were ligated and the eggs were examined for evidences of fertilization about $24 \mathrm{hr}$ after the injection of luteinizing hormone.

\section{RESULTS}

The oviduct of the hamster, as is shown diagrammatically in Text-fig. 1, is tortuous. Its ovarian end, i.e. infundibulum, is markedly inverted into the periovarian cavity. The caudal end of the oviduct joins the uterus, not at the very apex of the horn, but slightly below this point (Strauss, 1956; Bögli, 1959;

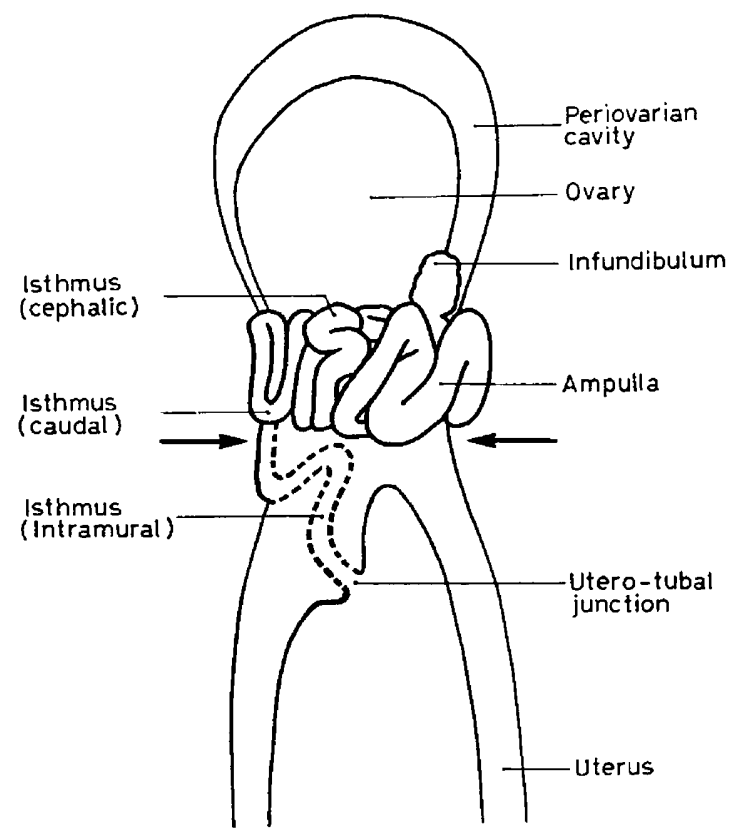

Text-Fig. 1. Diagrammatic sketch of the oviduct of the hamster. Arrows indicate site of ligation.

Oeri, 1960). In the present study, the oviduct was arbitrarily divided into five segments for the convenience of describing the results: (1) the infundibulum, the portion protruding into the periovarian cavity; (2) the ampulla, the ovarian section of oviduct involving the first three or four loops with a thin wall; (3) cephalic isthmus, the next three or four loops with a thicker wall and a markedly narrower lumen than the preceding sections; (4) the caudal isthmus, the portion composed of the succeeding three or four loops; (5) the intramural section of isthmus imbedded within the uterine wall. Cross sections through two different levels of the oviduct are shown in Pl. 1, Figs. 1 and 2.

Table 1 presents the essential data of experiments in which female hamsters were mated either before or after ovulation and the oviducts were ligated 0.5 to $6 \mathrm{hr}$ later. A total of sixty-five females were used in this experiment. It can 
be seen from Table 1 that when females were mated 5 to $8 \mathrm{hr}$ before ovulation and the oviducts were ligated $1 \mathrm{hr}$ later, only $16 \cdot 8 \%$ of the eggs were fertilized (against $100 \%$ fertilization in the unligated oviduct). Nine out of twelve females had no fertilized eggs in the ligated oviducts. In other words, ligation of the oviducts $\mathrm{I} \mathrm{hr}$ after mating markedly inhibited fertilization. The percentage of fertilized eggs increased as the time interval between mating and ligation was prolonged, and $81.4 \%$ of fifty-four eggs were fertilized when the oviducts were not ligated until $6 \mathrm{hr}$ after mating.

In the females mated $2 \mathrm{hr}$ after ovulation, on the other hand, even when the ligation was performed 30 min after mating, $37.5 \%$ of the eggs were fertilized. More than $90 \%$ of the eggs were fertilized when the oviducts were ligated $1 \mathrm{hr}$ after mating. Thus, a significantly higher percentage of eggs were fertilized following post-coital ligation of the oviducts in females mated after ovulation than in females mated before ovulation.

In order to examine whether the pattern of sperm distribution in the female

TABLE 1

FERTILIZATION OF HAMSTER EGGS IN THE LIGATED AND UNLIGATED OVIDUGTS

\begin{tabular}{|c|c|c|c|c|c|c|c|c|c|c|}
\hline \multirow{3}{*}{$\begin{array}{l}\text { Time of } \\
\text { mating }\end{array}$} & \multirow{3}{*}{$\begin{array}{c}\text { Interval } \\
\text { between start } \\
\text { of mating } \\
\text { and ligation } \\
\text { of oviducts } \\
(\mathrm{hr})\end{array}$} & \multirow{3}{*}{$\begin{array}{l}\text { No. } \\
\text { females } \\
\text { used }\end{array}$} & \multicolumn{2}{|c|}{$\begin{array}{l}\text { Females with fer- } \\
\text { tilized eggs in } \\
\text { ligated oviducts }\end{array}$} & \multicolumn{3}{|c|}{$\begin{array}{l}\text { Eggs recovered from } \\
\text { ligated oviducts }\end{array}$} & \multicolumn{3}{|c|}{$\begin{array}{l}\text { Eggs recovered from un- } \\
\text { ligated (control) oviducts }\end{array}$} \\
\hline & & & \multirow{2}{*}{ No. } & \multirow{2}{*}{$\%$} & \multirow{2}{*}{$\begin{array}{l}\text { Total } \\
\text { No. }\end{array}$} & \multicolumn{2}{|c|}{ Fertilized } & \multirow{2}{*}{$\begin{array}{l}\text { Total } \\
\text { No. }\end{array}$} & \multicolumn{2}{|c|}{ Fertilized } \\
\hline & & & & & & No. & $\%$ & & No. & $\%$ \\
\hline $\begin{array}{l}\text { About } 5 \text { to } \\
8 \text { hr before } \\
\text { ovulation }\end{array}$ & $\begin{array}{l}1 \\
2 \\
4 \\
6\end{array}$ & $\begin{array}{r}12 \\
9 \\
9 \\
10\end{array}$ & $\begin{array}{l}3 \\
7 \\
8 \\
9\end{array}$ & $\begin{array}{l}25 \\
78 \\
89 \\
90\end{array}$ & $\begin{array}{l}83 \\
53 \\
48 \\
54\end{array}$ & $\begin{array}{l}14 \\
21 \\
28 \\
44\end{array}$ & $\begin{array}{l}16 \cdot 8 \\
39 \cdot 6 \\
58 \cdot 3 \\
81 \cdot 4\end{array}$ & $\begin{array}{l}74 \\
43 \\
56 \\
55\end{array}$ & $\begin{array}{l}74 \\
43 \\
54 \\
55\end{array}$ & $\begin{array}{r}100 \cdot 0 \\
100 \cdot 0 \\
96 \cdot 5 \\
100 \cdot 0\end{array}$ \\
\hline $\begin{array}{l}\text { About } 2 \mathrm{hr} \\
\text { after ovula- } \\
\text { tion }\end{array}$ & $\begin{array}{l}0.5 \\
1\end{array}$ & $\begin{array}{l}12 \\
13\end{array}$ & $\begin{array}{l}10 \\
13\end{array}$ & $\begin{array}{r}83 \\
100\end{array}$ & $\begin{array}{l}80 \\
75\end{array}$ & $\begin{array}{l}30 \\
69\end{array}$ & $\begin{array}{l}37 \cdot 5 \\
92 \cdot 0\end{array}$ & $\begin{array}{l}89 \\
85\end{array}$ & $\begin{array}{l}88 \\
85\end{array}$ & $\begin{array}{r}98 \cdot 9 \\
100 \cdot 0\end{array}$ \\
\hline
\end{tabular}

Examined 10 to $12 \mathrm{hr}$ after the estimated time of ovulation.

tract is different between females mated before ovulation and those mated after ovulation, complete serial sections of the female tract were carefully studied. One hour from the start of mating was chosen for the time of comparison, because the ligations of oviducts performed at this time resulted in a distinct difference in respect to the rate of fertilization between the two groups of animals, as shown in Table 1. The results are summarized in Table 2. In the females mated $2 \mathrm{hr}$ after ovulation, all the uteri examined were found engorged with spermatozoa as shown in Pl. 2, Fig. 3. A fairly large number of spermatozoa were present in the utero-tubal junction and intramural portion of the isthmus (Pl. 2, Figs. 4 and 5). Many spermatozoa were also found in the caudal portions of the isthmus ( $\mathrm{Pl}$. 2, Fig. 6). The cephalic isthmus also contained spermatozoa, but far fewer than the caudal isthmus (Pl. 2, Fig. 7). In each of two females, a few spermatozoa were found in one of the ampullae (Pl. 2, Fig. 8). 


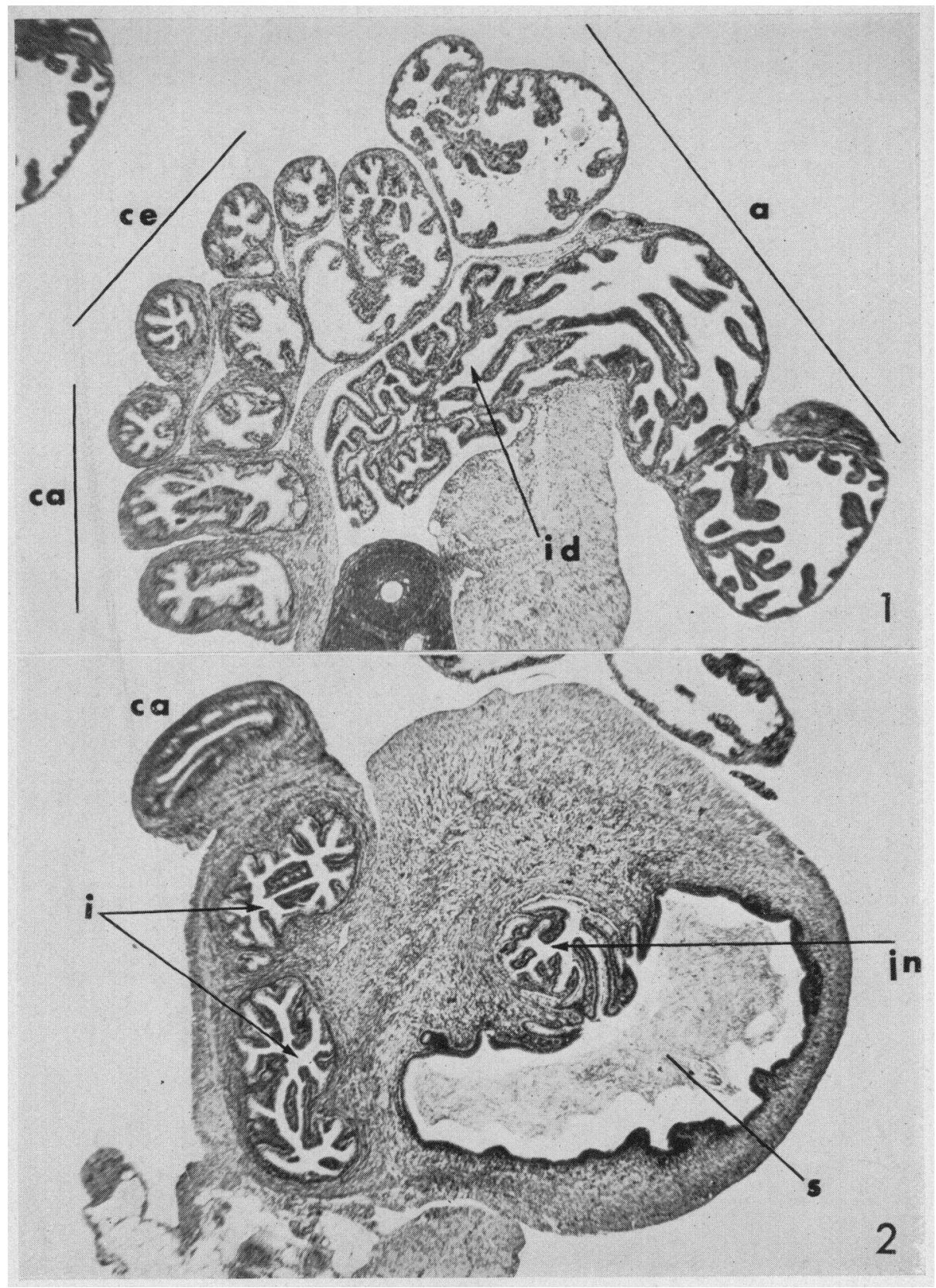

Photomicrographs of the oviduct and uterus taken from females mated about $2 \mathrm{hr}$ after ovulation and killed $1 \mathrm{hr}$ later.

FIG. 1. Gross section of the oviduct through infundibulum. $\times 30$.

FIG. 2. Cross section of the uterus through utero-tubal junction. $\times 30$.

Abbreviations: a, ampulla; ca, caudal isthmus; ce, cephalic isthmus; i, intramural isthmus; id, infundibulum; jn, utero-tubal junction; s, spermatozoa in uterine lumen.

(Faring P. 416) 


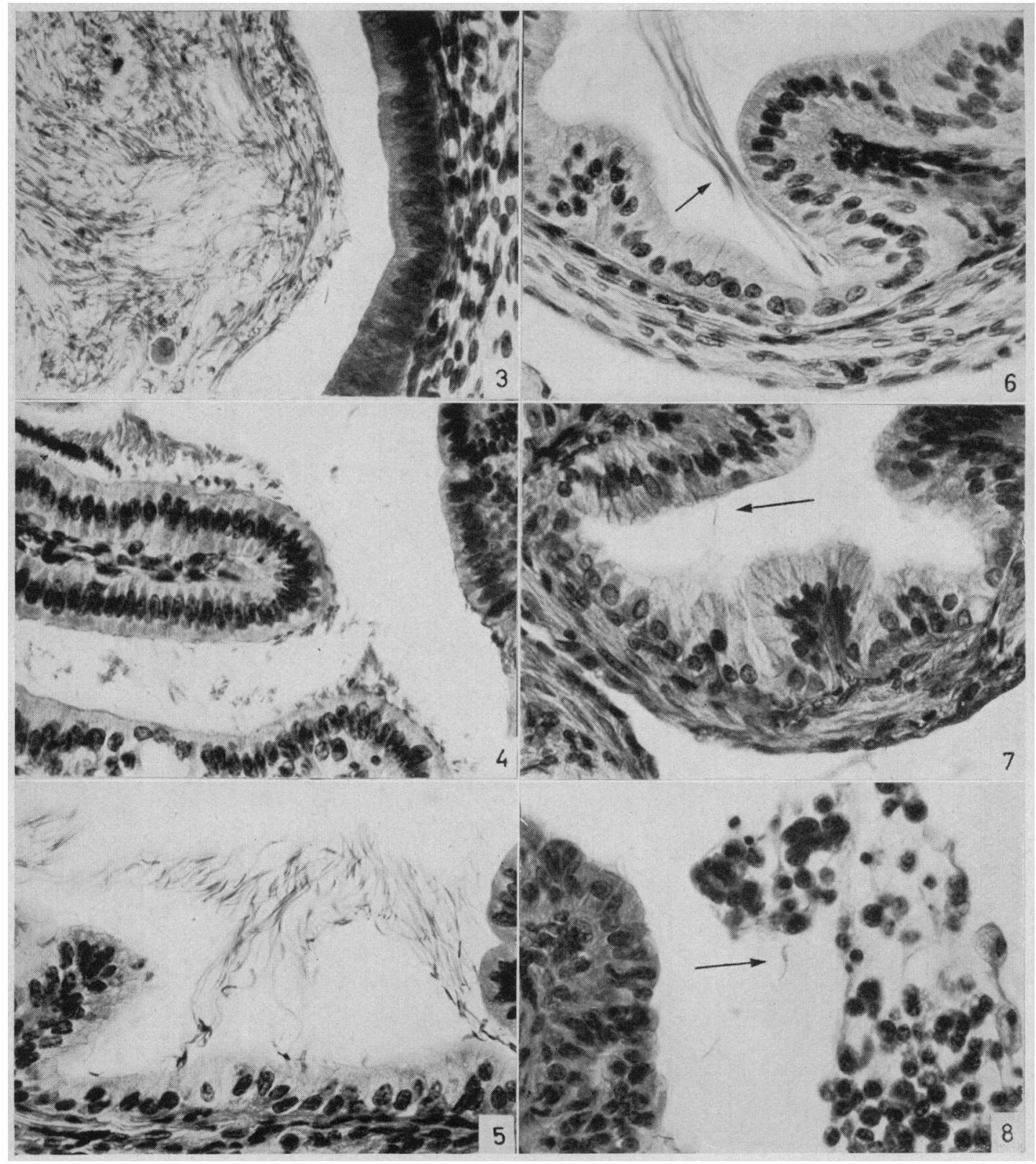

Photomicrographs of the oviduct and uterus taken from females mated about $2 \mathrm{hr}$ after ovulation and killed $1 \mathrm{hr}$ later.

FIG. 3. A part of the uterus, showing a dense mass of spermatozoa filling the uterine lumen. $\times 400$.

FIG. 4. Spermatozoa in the utero-tubal junction. $\times 400$.

FIG. 5. Spermatozoa in the intramural isthmus. $\times 400$.

Fig. 6. A group of spermatozoa (arrowed) found in the caudal isthmus. $\times 400$.

FIG. 7. A spermatozoon (arrowed) in the cephalic isthmus. $\times 400$.

FIG. 8. A spermatozoon (arrowed) present near cumulus oophorus in the ampulla. $\times 400$. 
In the females mated 5 to $8 \mathrm{hr}$ before ovulation, a vast number of spermatozoa were invariably found in the uterus. A large number of spermatozoa were

TABLE 2

PRESENCE OF SPERMATOZOA IN DIFFERENT PORTIONS OF THE FEMALE TRAGT FIXED 1 HR AFTER MATING

\begin{tabular}{l|c|c|c|c|c|c|c}
\hline & No. females & $\begin{array}{c}\text { No. uteri } \\
\text { containing } \\
\text { uspermatozoa }\end{array}$ & \multicolumn{4}{|c|}{ No. oviducts containing spermatozoa in } \\
\cline { 3 - 7 } & $\begin{array}{c}\text { Intramural } \\
\text { isthmus }\end{array}$ & $\begin{array}{c}\text { Caudal } \\
\text { isthmus }\end{array}$ & $\begin{array}{c}\text { Cephalic } \\
\text { isthmus }\end{array}$ & Ampulla \\
\hline $\begin{array}{l}\text { About } 5 \text { to } 8 \mathrm{hr} \\
\text { before ovulation }\end{array}$ & 6 & 12 & 12 & 11 & 0 & 0 \\
$\begin{array}{l}\text { About } 2 \mathrm{hr} \text { after } \\
\text { ovulation }\end{array}$ & 6 & 12 & 12 & 12 & 12 & 2 \\
\hline
\end{tabular}

also found in the intramural portion of the isthmus of all the females examined. Spermatozoa were present in the caudal isthmus, but in most cases they were found in the region close to the intramural portion of the isthmus. No sperma-

TABLE 3

FERTILIZATION OF RABBIT EGGS FOLLOWING THE LIGATION OF UTERO-TUBAL JUNCTION 2 HR AFTER MATING

\begin{tabular}{|c|c|c|c|c|}
\hline \multirow{2}{*}{ Time of mating } & \multirow{2}{*}{ Rabbit } & \multicolumn{3}{|c|}{ Eggs recovered } \\
\hline & & Total & Fertile & Fertile (\%) \\
\hline \multirow[t]{2}{*}{$\begin{array}{l}2 \mathrm{hr} \text { after luteinizing } \\
\text { hormone injection }\end{array}$} & $\begin{array}{l}1 \\
2 \\
3 \\
4 \\
5\end{array}$ & $\begin{array}{r}10 \\
14 \\
6 \\
10 \\
10\end{array}$ & $\begin{array}{r}0 \\
13 \\
0 \\
1 \\
2\end{array}$ & $\begin{array}{r}0 \\
93 \\
0 \\
10 \\
20\end{array}$ \\
\hline & Total & 50 & 16 & 32 \\
\hline \multirow[t]{2}{*}{$\begin{array}{l}6 \mathrm{hr} \text { after luteinizing } \\
\text { hormone injection }\end{array}$} & $\begin{array}{r}6 \\
7 \\
8 \\
9 \\
10\end{array}$ & $\begin{array}{l}7 \\
6 \\
9 \\
9 \\
8\end{array}$ & $\begin{array}{l}2 \\
6 \\
3 \\
0 \\
7\end{array}$ & $\begin{array}{r}29 \\
100 \\
33 \\
0 \\
88\end{array}$ \\
\hline & Total & 39 & 18 & 46 \\
\hline \multirow[t]{2}{*}{$\begin{array}{l}12 \mathrm{hr} \text { after luteinizing } \\
\text { hormone injection }\end{array}$} & $\begin{array}{l}11 \\
12 \\
13 \\
14 \\
15\end{array}$ & $\begin{array}{r}9 \\
10 \\
7 \\
9 \\
8\end{array}$ & $\begin{array}{l}3 \\
0 \\
0 \\
0 \\
0\end{array}$ & $\begin{array}{r}33 \\
0 \\
0 \\
0 \\
0\end{array}$ \\
\hline & Total & 43 & 3 & 7 \\
\hline
\end{tabular}

tozoa were observed in the cephalic isthmus or the ampulla of any of the females examined. It is obvious that a larger proportion of spermatozoa reached the upper portion of the oviduct in females mated after, than in those mated 
before, ovulation. It seems, therefore, that sperm ascent into the upper region of the oviduct is faster when mating occurs after ovulation.

Table 3 presents the results of experiments in which female rabbits were mated with a fertile male at a certain time before or after ovulation, the uterotubal junction being ligated $2 \mathrm{hr}$ after mating. It is apparent from the proportion of eggs fertilized in each group that there is no indication that the sperm ascent to the site of fertilization in the rabbit is faster when mated after ovulation than before ovulation, although sperm transport may be faster $4 \mathrm{hr}(6 \mathrm{hr}$ after injection) before ovulation than $8 \mathrm{hr}$ ( $2 \mathrm{hr}$ after injection) before ovulation.

\section{DISCUSSION}

It was quite unexpected that high percentages of the hamster eggs were not fertilized when females were mated before ovulation and their oviducts were ligated 1 to $2 \mathrm{hr}$ later, because Yamanaka \& Soderwall (1960) reported that the spermatozoa could be recovered from the ampullary portion of the hamster oviduct within 2 min after ejaculation. It is possible that ligation of the oviduct may disturb the fertilizing capacity of spermatozoa trapped in the ampulla. Leonard (1950) reported that when female rats were mated in the early evening (probably several hours before ovulation) and the utero-tubal junction was ligated 1 to $5 \mathrm{hr}$ after copulation, most of the eggs (98.4\%) were not fertilized. Leonard surmised that this failure of fertilization was associated with a marked accumulation of fluid in the periovarian cavity which might interfere with the normal ascent of the spermatozoa to the site of fertilization. In the hamster, the ligation of utero-tubal junction or the uterine end of the oviduct did not induce any marked accumulation of fluid in the periovarian cavity. Although the ampullary portion of the oviduct was distended with fluid at the time of the recovery of eggs (about 10 to $12 \mathrm{hr}$ after ovulation), there was no marked difference in the degree of fluid accumulation between the ligated and the unligated oviduct. Thus the failure of fertilization of the hamster eggs in the ligated oviduct cannot be attributed to the accumulation of fluid in the periovarian cavity or in the oviduct. It appears from histological examination of oviducts in the present study that the failure of fertilization is due to a small number of spermatozoa entering the upper portion of the oviduct (Table 2).

As described by Chang \& Sheaffer (1957) and confirmed in the present study, a vast number of spermatozoa are deposited in the uterus of the hamster at copulation. A fairly large number of spermatozoa also pass rather promptly into both the intramural and caudal portions of the isthmus. However, as shown by serial sections, hamster spermatozoa seldom reached the ampullary portion of the oviduct within $1 \mathrm{hr}$ after mating. This was especially true when females were mated before ovulation. Thus, the remarkably rapid sperm transport to the ampulla of the hamster oviduct reported by Yamanaka \& Soderwall (1960) is subject to further critical examination. Contamination of the sample with uterine spermatozoa may have occurred in their study.

The rate of sperm ascent appears to beinfluenced by the time of mating in the rat, as in the hamster. According to Braden \& Austin (1954) the number of spermatozoa recovered from the ampullae of rats several hours after mating was significantly 
higher when females were mated during or after ovulation than when they were mated before ovulation. These authors expressed the opinion that the restriction on the passage of spermatozoa through the female tract is relaxed towards the end of oestrus and that such a relaxation may not exist in the rabbit, because the number of spermatozoa found in the oviduct 4 to $6 \mathrm{hr}$ after copulation is not significantly different between females mated normally (i.e. about $10 \mathrm{hr}$ prior to ovulation) and those mated about the time of ovulation (Braden \& Austin, 1954). Although our experimental results in the rabbit confirm their observations, we think that such a relaxation, or rather change in activity, may also exist in the rabbit. We think that the different results obtained in the hamster and rabbit is due to the fact that in the hamster hundreds of millions of spermatozoa are almost directly deposited into the uterus, whereas in the rabbit spermatozoa are ejaculated into the vagina and only a small fraction get into the uterus. It may be that transport of spermatozoa is quicker after ovulation in the rabbit, but that it does not show up because the anatomy of the female tract is different, and because only relatively few spermatozoa enter the uterus. If this is so, then we would expect sperm ascent not to be faster after ovulation in the cow or sheep, and perhaps in women. On the other hand, we would expect a fast sperm ascent after ovulation in the rat, in the pig, and perhaps in the mare, because in these species a large volume of semen is ejaculated into the uterus, as in the hamster.

Farris (1942) reported that in the rat the spermatozoa were transported from the uterus to the oviduct only just before or at the time of ovulation, suggesting a long sojourn of spermatozoa in the uterus before they enter the oviduct. It is unlikely that none of the spermatozoa enter the oviduct until the time of ovulation, because Blandau \& Money (1944) were able to recover spermatozoa from both uterine and ovarian segments of the oviduct $1 \mathrm{hr}$ after mating. However, it is quite possible that a large number of spermatozoa do not start to migrate from the uterus towards the upper portion of the oviduct until just before or after ovulation. In this connexion, the results of experiments involving post-coital ligation of the rat oviduct are of special interest. Leonard (1950) found that when the oviduct was ligated around the utero-tubal junction between 1 and $5 \mathrm{hr}$ after mating, a very low percentage of eggs was fertilized, as mentioned previously. Alden (1942), on the other hand, observed many normally developing eggs in the oviducts ligated about $6 \mathrm{hr}$ after mating. These contradictory observations may suggest that a considerable time ( 5 to 6 $\mathrm{hr}$ or more) is required before sufficient spermatozoa enter the oviducts to fertilize all the viable eggs.

\section{ACKNOWLEDGMENTS}

The work was supported by grants from U.S. Public Health Service RG-0816704 and a P.H.S. Research Career Award (GM-K6-18-334).

\section{REFERENCES}

Adams, C. E. (1956) A study of fertilization in the rabbit: The effect of post-coital ligation of the Fallopian tube or uterine horn. 7. Endocrin. 13, 296.

ALDEN, R. H. (1942) Aspects of egg-ovary-oviduct relationship in the albino rat. II. Egg development within the oviduct. F. exp. Zool. 90, 171. 
Blandau, R. J. (1952) The female factor in fertility and infertility. I. Effects of delayed fertilization on the development of the pronuclei in rat ova. Fertil. Steril. 3, 349.

Blandau, R. J., Boling, J. L. \& Young, W. C. (1941) The length of heat in the albino rat as determined by the copulatory response. Anat. Rec. 79, 453.

Blandau, R. J. \& Money, W. L. (1944) Observations on the rate of transport of spermatozoa in the female genital tract of the rat. Anat. Rec. 90, 255.

BöGLI, B. (1959) Das tubo-uterine Ventil beim Gold-hamster. Rev. suisse Zool. 66, 211.

Boling, J. L., Blandau, R. J., Soderwall, A. L. \& Young, W. C. (1941) Growth of the Graafian follicle and the time of ovulation in the albino rat. Anat. Rec. 79, 313.

BRADEN, A. W. H. (1953) Distribution of sperms in the genital tract of the female rabbit after coitus. Aust. 7. biol. Sci. 6, 693.

Braden, A. W. H. \& Austin, C. R. (1954) The number of sperms about the eggs in mammals and its significance for normal fertilization. Aust. 7. biol. Sci. 7, 543.

Chang, M. C. \& Sheaffer, D. (1957) Number of spermatozoa ejaculated at copulation, transported into the female tract, and present in the male tract of the golden hamster. F. Hered. 48, 107.

FarRIs, E. J. (1942) Studies of reproduction in the albino rat. Anat. Rec. 84, 454.

GreEnwald, G. S. (1956) Sperm transport in the reproductive tract of the female rabbit. Science, 124, 586.

HaRvey, E. B., Yanagimachi, R. \& Chang, M. C. (1961) Onset of estrus and ovulation in the golden hamster. F. exp. Zool. 146, 231.

LeONard, S. L. (1950) The reduction of uterine sperm and uterine fluid on fertilization of rat ova. Anat. Rec. 106, 607.

LEwIs, W. H. \& WRIGHT, E. S. (1935) On the early development of the mouse egg. Carnegie Instn. Contrib. Embryol. 25, 115.

Oerr, H. U. (1960) Der Bau des Eileiters beim Gold-hamster (Mesocricetus auratus). Z. Säugetierk. $25,52$.

Soderwall, A. L., Kent, H. A., Turbyfill, C. L. \& Britenbaker, A. L. (1960) Variation in gestation length and litter size of the golden hamster, Mesocricetus auratus. F. Geront. 15, 246.

Strauss, F. (1956) The time and place of fertilization of the golden hamster egg. F. Embryol. exp. Morph. 4,42 .

Yamanaka, H. S. \& Soderwall, A. L. (1960) Transport of spermatozoa through the female genital tract of hamsters. Fertil. Steril. 11, 470.

Yanagimachi, R. \& Chang, M. C. (1961) Fertilizable life of golden hamster ova and their morphological changes at the time of losing fertilizability. F. exp. Zool. 148, 185. 